\title{
Uncaria Tomentosa Extract: Evaluation of Effects on the in Vitro and in Vivo Labeling of Blood Constituents with Technetium-99m
}

\author{
Silvana Ramos Farias Moreno ${ }^{1,2,5^{*}}$, Jorge José de Carvalho ${ }^{3,5}$, Ana Lúcia Nascimento ${ }^{3,5}$, \\ Beni Olej ${ }^{1}$, Emely Kazan Rocha ${ }^{4,5}$, Adriano Arnobio ${ }^{1}$, Mário Bernardo-Filho ${ }^{2,5}$; Luiz \\ Querino de Araújo Caldas ${ }^{1}$ and Hayden Honeycut ${ }^{6}$ \\ ${ }^{1}$ Universidade Federal Fluminense; Rua Marquês de Paraná, 303; 24030210; srfmoreno@hotmail.com; Niterói - \\ $R J$ - Brasil. ${ }^{2}$ Departamento de Biofísica e Biometria; Rio de Janeiro - RJ - Brasil. ${ }^{3}$ Departamento de Histologia e \\ Embriologia; Rio de Janeiro - RJ - Brasil. ${ }^{4}$ Departamento de Biologia Celular e Genética; Rio de Janeiro - RJ - \\ Brasil. ${ }^{5}$ Instituto de Biologia Roberto de Alcântara Gomes; Universidade do Estado do Rio de Janeiro; Av. 28 de \\ Setembro, 87; Rio de Janeiro; 20551030; Rio de Janeiro - RJ - Brasil. ${ }^{6}$ School of Pharmacy; University of North \\ Carolina; Chapel Hill;27599-7360, North Carolina - USA
}

\begin{abstract}
The influence (in vivo and in vitro) of an Uncaria tomentosa extract (Cats claw) on the labeling of red blood cells (RBCs) and plasma and cellular proteins with technetium-99m (Tc-99m) was evaluated. For the in vivo treatment, animals were treated with Cats claw. For the in vitro treatment, heparinized blood was incubated with Cats claw before the addition of stannous chloride $\left(\mathrm{SnCl}_{2}\right)$ and $\mathrm{Tc}-99 \mathrm{~m}$. Samples of plasma $(P)$ and RBCs were separated and also precipitated with trichloroacetic acid. The soluble and insoluble fractions of $P$ and RBCs were isolated. The analysis of the results of the in vivo study, indicates that there is no significant alteration on the uptake of Tc-99m by the blood constituents, but it significantly decrease $(p<0.05)$ the labeling of blood constituents by in vitro methods. These effects could be due to chelation of stannous and /or pertechnetate ions and blockage of the Tc-99m bindings sites.
\end{abstract}

Keywords: Uncaria tomentosa, technetium-99m, radiolabeling, blood constituents

\section{INTRODUCTION}

Medicinal plants have been used in many cultures. Biological effects due to the use of medicinal plants have been reported (Rotblatt et al., 2002). Uncaria tomentosa, also known as unha de gato ('Cats claw' in English), has become widely known as an useful plant in ethnomedicine. This plant is traditionally used to treat arthritis and rheumatism, ulcers and other disorders of the gastrointestinal tract, asthma, gonorrea, dengue, dysentery and tumors (Rotblatt et al., 2002; Pilarski et al., 2006; Reis et al., 2008). No side effects were reported in the few human studies, and no adverse effects were found in rodents (Rotblatt et al., 2002). Uncaria-drugs interactions have not been well reported, but one in vitro study

\footnotetext{
Author for correspondence
} 
revealed Cats claw inhibition activity on the $3 \mathrm{~A} 4$ isozime of cytochrome P450 (Reis et al., 2008).

There are some studies about the effect of natural products on the labeling of blood constituents using technetium-99m (Tc-99m) (Lima et al., 2002; Oliveira et al., 1997; Braga et al., 2000; Oliveira et al., 2002; Oliveira et al., 2003; Dantas et al., 2005; Oliveira-Fernandes et al., 2005; Abreu et al., 2006; Neves et al., 2007; Rebello et al., 2007; Sinzinger et al., 2007). It has been reported that Fucus vesiculosus (Oliveira et al., 2003), Ginkgo biloba (Moreno et al., 2004), Psidium guajava (Abreu et al., 2006), Vellozia pusilla (Dantas et al., 2005) and Arctium lappa (Neves et al., 2007) extracts are capable of altering the radiolabeling of blood constituents.

The alteration of fixation of Tc-99m on the blood constituents promoted by some drugs has been associated with a possible oxidation of the stannous ion (Bernardo-Filho et al., 2005).

The aim of this work was to evaluate the effect of an Uncaria tomentosa (U. tomentosa) extract on the labeling of blood constituents with Tc-99m using in vivo and in vitro models.

\section{MATERIAL AND METHODS}

Commercial Uncaria tomentosa (Cats claw, Herbarium Foundation for Health and Research, Brazil Lot $\mathrm{n}^{\circ}$ 923661) was purchased and aqueous preparations $(32 \mathrm{mg} / \mathrm{mL})$ were prepared using a $\mathrm{NaCl} 0.9 \%$ solution. Female Wistar rats (2 month-old and 180-210g) were obtained from Universidade do Estado do Rio de Janeiro, Brazil). Experiments were conducted in accordance with the Committee of Animal Care (Giles, 1987). The preparation was administered to female Wistar rats (7 days, intragastric via). Tc$99 \mathrm{~m}$, as sodium pertechnetate $(0.3 \mathrm{~mL}, 3.7 \mathrm{MBq}$, Instituto de Pesquisas Energéticas e Nucleares, $C N E N$, São Paulo, Brazil) freshly milked from a ${ }^{99}$ Molybdenium $/{ }^{99 \mathrm{~m}}$ Technetium generator was injected into the ocular plexus and the animals were sacrificed (after 10 minutes). For the in vivo study, blood samples $(0.5 \mathrm{~mL})$ were obtained from these rats treated with Cats claw $(32 \mathrm{mg} / \mathrm{mL}, \mathrm{n}=6)$. For the in vitro study, blood samples $(0.5 \mathrm{~mL}$, $\mathrm{n}=6$ ) obtained from the rats were incubated (60 minutes) with $100 \mu \mathrm{L}$ of the Cats claw (32 $\mathrm{mg} / \mathrm{mL}$ ). The blood samples (in vitro and in vivo studies) received $0.5 \mathrm{~mL}$ of freshly prepared stannous chloride solution $(1.2 \mu \mathrm{g} / \mathrm{mL}$, Sigma Chemical Co. St Louis, USA, Lot 65H26736), under vacuum conditions and the incubation was continued for 60 minutes. Then, $100 \mu \mathrm{L}$ of Tc99m (3.7 MBq/mL, Instituto de Pesquisas Energéticas e Nucleares, CNEN, São Paulo, Brazil, from a ${ }^{99}$ Molybdenium $/{ }^{99 \mathrm{~m}}$ Technetium generator as sodium pertechnetate) was added (10 minutes). The samples were centrifuged for 5 minutes, and plasma (P) and blood cells (BC) were separated. Samples $(20 \mu \mathrm{L})$ of $\mathrm{P}$ and $\mathrm{BC}(20 \mu \mathrm{L})$ were also precipitated with $1 \mathrm{~mL}$ of trichloroacetic acid (TCA 5\%) and soluble (SF) and insoluble fractions (IF) were separated by centrifugation. The radioactivity in $\mathrm{BC}$, IF-P and IF-BC were determined in a sodium iodide well counter (Automatic Gamma Counter, C5002, Packard, USA) and the percent of administered radioactivity (\% ATI) was calculated. The results are presented as mean and standard diversion (S.D.), with a statistical analysis performed (ANOVA test, Tukey-Kramer test and Dunnet test).

\section{RESULTS}

Table 1 shows the distribution of the radioactivity in RBCs, the insoluble fraction of plasma (IF-P) and of blood cells (IF-BC) from whole blood of animals treated with Uncaria tomentosa extract (Cats claw). The results indicate no significant alteration in the uptake of Tc-99m by the blood cells. The same result was found with samples of plasma proteins (insoluble fraction of plasma, IF$\mathrm{P}$ ) and of cell proteins (insoluble fraction of blood cells, IF-BC) obtained from animals treated $(\mathrm{P}>0.05$, table 1$)$.

Table 1 - In vivo Study: Effect of an Uncaria tomentosa extract on the labeling of blood cells (BC) with Tc-99m and on the distribution of this radionuclide in the insoluble fractions of the plasma (IF-P) and of the blood cells (IFBC) obtained after the labeling.

\begin{tabular}{cccc}
\hline U. tomentosa & BC & IF-P & IF-BC \\
\hline Control & $91.6 \pm 3.9$ & $69.5 \pm 1.8$ & $74.2 \pm 1.9$ \\
$32 \mathrm{mg} / \mathrm{mL}$ & $97 \pm 0.7$ & $73.3 \pm 0.9$ & $76.7 \pm 2.4$ \\
\hline
\end{tabular}


Table 2 shows a significant decrease in the Tc$99 \mathrm{~m}$ uptake by RBCs from $98.6 \pm 1.9$ to $55.4 \pm 0.7$ $(\mathrm{p}<0.05)$ in samples treated in vitro with Cats claw. This table also shows that the \% ATI in the
IF-P and in the IF-BC obtained from this same blood significantly decreased $(\mathrm{p}<0.05)$ from $68.1 \pm 4.8$ to $11.6 \pm 3.4$ and from $76.7 \pm 2.4$ to $19.8 \pm 4.4$, respectively.

Table 2- In vitro Study: Effect of an Uncaria tomentosa extract on the labeling of blood cells with Tc-99m and on the distribution of this radionuclide in the insoluble fractions of the plasma (IF-P) and of the blood cells (IF-BC) obtained after the labeling.

\begin{tabular}{cccc}
\hline U. tomentosa & BC & IF-P & IF-BC \\
\hline Control & $98.6 \pm 1.9$ & $68.1 \pm 4.8$ & $76.7 \pm 2.4$ \\
$32 \mathrm{mg} / \mathrm{mL}$ & $55.4 \pm 0.7$ & $* 11.6 \pm 3.4$ & $19.8 \pm 4.4$ \\
\hline
\end{tabular}

$* P<0.05$.

\section{DISCUSSION}

Medicine-Uncaria interactions have not been objectively evaluated in published peer-reviewed studies (Rotblatt et al., 2002; Pilarski et al., 2006; Reis et al., 2008). Thus, it is important to develop models that can describe the possible in vitro and in vivo drug interactions.

Some authors have described that synthetic or natural products, can alter the labeling of blood constituents with Tc-99m (Braga et al., 2000; Gomes et al., 2002; Bernardo-Filho et al., 2005; Neves et al., 2007).

Moreno et al., (2004), have evaluated the effect of a Ginkgo biloba extract on labeling of blood constituents with Tc-99m using in vitro and in vivo study: a reduction of radiolabeling of blood cells was observed with the in vitro method (Moreno et al., 2004). Psidium guajava extract reduces the radioactivity uptake in IF-P (plasma proteins) and $\mathrm{BC}$ (blood cells) when used with an in vitro assay (Abreu et al., 2006). Neves et al., (2007) have reported that an Arctium lappa (burdock) extract significantly decrease the in vitro radiolabeling efficiency of blood cells. Rebello et al. (2007) studied the in vitro effect of a peel passion fruit flour on the labeling of blood constituents with Tc$99 \mathrm{~m}$. Their findings demonstrated a significant reduction of plasma proteins labeled with Tc-99m (Rebello et al., 2007).

Active chemical constituents of $U$. tomentosa include alkaloids, quinovic acid glycosides, polyhydroxylated triterpenes and several steroidal components (Rotblatt et al., 2002). These substances may be associated with the imunomodulatory, anti-inflammatory and anticancer properties, and also could be associated with the effect on the blood constituents radiolabeling. Therefore, the capacity of the $U$. tomentosa extract to inhibit the activity of the 3A4 isozime of cytochrome P 450 (Rotblatt et al., 2002) suggests that this extract has constituents that could be blockers of calcium channels (Klassen, 2001), preventing the entrance of stannous chloride in the cell. This mechanism may explain the effect on the radiolabeling of blood constituents promoted by the Cats claw (Table 2). As tannins (fractions of $U$. tomentosa extract) can precipitate proteins (Rotblatt et al., 2002), this also could explain the interference of the extract on the labeling of cells and plasma proteins. The in vitro effect of the Uncaria tomentosa extract on radiolabeling of blood constituents may be due to four possible mechanisms: (i) chelation of stannous and/or pertechnetate ions; (ii) competition of $\mathrm{Tc}-99 \mathrm{~m} / \mathrm{stannous}$ ions by the bindings sites; (iii) interference in the redox state of the labeling system, and (iv) blockage of calcium channels (Hesslewood et al., 1994; Bernardo-Filho et al., 2005). Results obtained from blood of animals treated with the extract, have shown that metabolization of Uncaria tomentosa extract after in vivo treatment was unable to alter the labeling of the blood constituents. Similar findings were reported for the Pfaffia sp. extract, wich also does not alter the labeling of blood constituents with technetium$99 \mathrm{~m}$ when an in vivo model was employed (Oliveira-Fernandes et al., 2005).

In conclusion, the interference of Uncaria tomentosa components in the radionuclide labeling method may be explained by: chelation of stannous and/or pertechnetate ions; blockage of the Tc-99m binding sites and effect in the redox state of the labeling system. 


\section{ACKNOWLEDGEMENTS}

The present work was carried out with support of the CAPES, CNPq, UERJ and UFF. The authors are also grateful to Michael G. Stabin, PhD, CHP, Department of Radiology and Radiological Sciences, Vanderbilt University, Nashville, for revisions to the English grammar in the paper.

\section{RESUMO}

O objetivo do presente estudo foi avaliar a influência (in vivo e in vitro) de um extrato de Uncaria tomentosa (unha de gato) na marcação de hemácias e proteínas plasmáticas e celulares com tecnécio-99m (Tc-99m). Para o estudo in vivo, animais foram tratados com um extrato de unha de gato. Para o estudo in vitro, sangue heparinizado foi incubado com o extrato de unha de gato antes da adição de cloreto estanoso $\left(\mathrm{SnCl}_{2}\right)$ e Tc-99m. Amostras de plasma e células foram separadas e também precipitadas com ácido tricloracético. As frações solúveis e insolúveis foram isoladas. A análise dos resultados do estudo in vivo, indica que não houve alteração significante na captação de Tc-99m pelos constituintes sanguíneos, entretanto, no tratamento in vitro, ocorreu redução significante da marcação de constituintes sanguíneos. Esses efeitos poderiam ser justificados por quelação dos íons estanoso e pertecnetato e bloqueio dos sítios de ligação do Tc-99m.

\section{REFERENCES}

Abreu, P. R. C.; Almeida, M. C.; Bernardo, R. M.; Bernardo, L. C., Brito, L. C.; Garcia, E. A. C.; Fonseca, A. S. (2006), Bernardo-Filho, M. Guava extract (Psidium guajava) alters the labeling of blood constituents with technetium-99m. J. Zhejiang Univ. Sci., 7, 429-35.

Bernardo-Filho, M.; Santos-filho, S. D. E.; Moura, E. G.; Maiwarm, A. I., Orlando, M. M. C.; Pena, M. E. (2005), Drug interaction with radiopharmaceuticals: a Review. Braz. Arch. Biol. Technol., 28, 13-27.

Braga, A. C. S.; Oliveira, M. B. N.; Feliciano, D.; Reiniger, I. W.; Oliveira, J. F.; Silva, C. R.; Bernardo-Filho, M., (2000), The effect of drugs on the labeling of blood elements with technetium-99m. Curr. Pharm. Design., 6, 1179-1191.
Dantas, A. L.; Valente, L. M. M. V.; Moraes, L. A. S.; Feliciano, G.; Bernardo-Filho, M., (2005), In vitro study of Vellozia pusilla Pohl (Velloziaceae) brazilian species of plant: Antitumoral activity and labeling of blood elements. Braz. Arch. Biol. Technol ., 48, 63-68.

Diré, G. F.; Lima, E.; Gomes, M. L.; Moreno, S.; Faria, M. V. C.; Jales, R. L.; Bernardo-Filho, M. (2003), Evaluation of the Biological effects of a natural extract of chayotte (Sechium edule): A molecular and cellular analysis. Pak. J. Nut., 2, 249-253.

Giles, A. R.(1987), Guidelines for the use of animals in biomedical research. Thromb. Haemost., 58, 10781984.

Gomes, M. L.; Oliveira, M. N.; Bernardo-Filho, M. (2002), Drug interaction with radiopharmaceuticals: Effect on the labeling of red blood cells with technetium-99m and on the bioavailability of radiopharmaceuticals. Braz. Arch. Biol. Technol., 45, 143-149.

Hesslewood, S.; Leungeung, E. (1994), Drug interactions with radiopharmaceuticals. Eur. J. Nucl. Med., 21, 348-356.

Klassen. In Casarett, Doull's. (2001), Toxicology: The Basis Science of Poisons. $6^{\mathrm{a}}$ Edition. Macmillan Publishing Company, New York.

Lima, E. A. C.; Diré, G.; Mattos, D. M.; Gomes, M. L.; Oliveira, M. B.; Faria, M. V. C.; Bernardo-Filho, M. (2002), Effect of an extract of cauliflower (leaf) on the labeling of blood elements with technetium-99m and on the survival of Escherichia coli AB1157 submitted to the treatment with stannous chloride. Food Chem. Toxicol., 40, 919-923.

Moreno, S. R. F.; Freitas, R. S.; Rocha, E. K.; LimaFilho, G. L.; Bernardo-Filho, M. (2004), Protection of plasmid DNA by Ginkgo biloba from the effects of stannous chloride and the action on the labeling of blood elements with technetium-99m. Braz. J. Med. Biol. Res., 37, 267-271.

Neves, R.F.; Moreno, S. R. F.; Rebello, B. M.; Caldas, L. Q. A.; Fonseca, A. S.; Bernardo-Filho, M.; Medeiros, A. C. (2007), Effect of an Arctium lappa (burdock) Extract on the labeling of blood constituents with Technetium-99m and on the morphology of Red blood cells. Braz. Arch. Biol. Technol., 50, 167-74.

Oliveira, J. F.; Braga, A. C. C.; Ávila, A. S.; Fonseca, L. B., Gutfilen, B.; Bernardo-Filho, M. (1997), Effect of Thuya occidentalis on the labeling of red blood cells and plasma proteins with technetium99m. The Yale J. Biol. Med., 69, 489-494.

Oliveira, J. F.; Ávila, A. S,; Braga, A. C. S.; Oliveira, M. B. N.; Boasquevisque, E. M.; Jales, R. L.; Bernardo-Filho, M. (2002), Effect of extract of medicinal plants on the labeling of blood elements with technetium- $99 \mathrm{~m}$ and on the morphology of red blood cells: I - a study with Paullinia cupana. Fitoterapia, 73, 305-312. 
Oliveira, J. F.; Oliveira, M. B.; Ávila, A. S.; Braga, A. C. S.; Catanho, M. T. J. A.; Jales, R. L. C. (2003), Assessment of the effect of Fucus vesiculosus extract on the labeling of blood constituents with technetium$99 \mathrm{~m}$ and the histological modifications on the shape of the red blood cells. Food Chem. Toxicol., 41, 1520.

Oliveira-Fernandes, J. F.; Brito, L. C.; Frydman, J. N. G.; Santos-Filho, S.; Bernardo-Filho, M.(2005), An aqueous extract of Pfaffia sp. does not alter the labeling of blood constituents with technetium-99m and morphology of the red blood cells. Braz. J. Pharmacognosy., 15, 126-132.

Pilarski, R.; Zienlinski, H.; Ciesiolka, D.; Gulewicza, K. (2006), Antioxidant activity of ethanolic and aqueous extracts of Uncaria tomentosa (willd) DC. $J$. Ethnopharm., 104, 18-23

Rebello, B. M.; Moreno, S. R. F.; Godinho, C. R.; Neves, R. F.; Fonseca, A. S.; Caldas, L. Q. A.; Bernardo-Filho, M.; Medeiros, A. C. (2007), Effect of a Peel Passion Fruit Flour (Passiflora edulis $f$. flavicarpa) Extract on the labeling of blood constituents with technetium-99m and on the morphology of red blood cells. Braz. Arch. Biol. Technol., 50, 153-59.
Reis, S. R. I. N.; Valente, L. M.; Sampaio, A. L.; Siani, A. C.; Gardini, M.; Azevedo, E. L.; D’Ávila, L. A.; Mazzi, J. L.; Henriques, M. G.; Kubelka, C. F. (2008), Immunomodulating and antiviral activities of Uncaria tomentosa on human monocytes infected with dengue virus-2. J. Int. Inmunopharm., 8, 468-76.

Rotblatt, M.; Ziment, I. (2002), Evidence-Based Herbal Medicine. Philadelphia: Hanley and Belfus, Med. Publishers.

Sinzinger, H; Rodrigues, M. (2007), Cellular labeling with Tc-99m chelates: Relevance of in vitro and in vivo viability testing. In: Zolle I (ed.) Technetium$99 \mathrm{~m}$ pharmaceuticals: Preparation and quality control in nuclear medicine. Springer, Berlin.
Received: August 15, 2008; Revised: September 11, 2008; Accepted: September 13, 2008 